\title{
APPLICATION OF GIS TECHNOLOGIES TO DISPLAY \\ OF ARCHAEOLOGICAL HERITAGE IN THE \\ REPUBLIC OF TATARSTAN
}

\section{APLICACIÓN DE TECNOLOGÍAS SIG PARA LA VISUALIZACIÓN DEL PATRIMONIO ARQUEOLÓGICO EN LA REPÚBLICA DE TATARSTÁN}

\author{
Irina A. Rysaeva ${ }^{1}$, Farida Z. Rafikova ${ }^{1}$, Nikita S. Gladnev ${ }^{1}$ \\ ${ }^{1}$ Kazan, Kazan Federal University \\ Farida.rafikova@mail.ru
}

Enviado: 27 de junio de 2019

Aceptado para publicar: 30 de julio de 2019

Publicado: 8 de agosto de 2019

\begin{abstract}
The article describes the experience of developing GIS technologies of the archaeological heritage in the Republic of Tatarstan for further detailed study, conservation, keeping and systematization. Considered tools, sources of information, structure GIS and final products. The composition of the archaeological heritage includes burial and burial ground, settlement, settlements management, settlements, settlement, stone pillars, tombstones, places of old settlements, sanctuaries etc. To resolve this problem was created a GIS database that serves as the basis of archaeological GIS in the Republic of Tatarstan. A geodatabase was created on the platform ArcGIS. It includes a description of the monuments of archaeology, which contains geographic (spatial) and attributive (descriptive) information. The main criterion for determining the scale of mapping of the territory is the spatial placing of objects of archaeological heritage.
\end{abstract}

Keywords: GIS technology, digital map, historical and cultural heritage, spatial position.

El artículo describe la experiencia de desarrollar tecnologías SIG del patrimonio arqueológico en la República de Tatarstán para un estudio más detallado, conservación, mantenimiento y sistematización. Herramientas consideradas, fuentes de información, estructura de SIG y productos finales. La composición del patrimonio arqueológico incluye entierros y cementerios, asentamientos, gestión de asentamientos, asentamientos, asentamientos, pilares de piedra, lápidas, lugares de antiguos asentamientos, santuarios, etc. Para resolver este problema, se creó una base de datos SIG que sirve de base para la arqueología. SIG en la República de Tatarstán. Se creó una geodatabase en la plataforma ArcGIS. Incluye una descripción de los monumentos de la arqueología, que contiene información geográfica (espacial) y atributiva (descriptiva). El criterio principal para determinar la escala de mapeo del territorio es la colocación espacial de objetos de patrimonio arqueológico.

Palabras clave: tecnología SIG, mapa digital, patrimonio histórico y cultural, posición espacial. 


\section{Introduction}

The study of archaeological sites has important international value, they are part of the cultural heritage of the country and its historical past. A large number of archaeological objects and their spatial separation, and the variety of factors of destruction make it extremely topical application of geographic information systems allowing to solve tasks of analysis to make the monitoring and forecast of the state of archaeological monuments [1]. Archaeological GIS necessary tool for identification, tracking, inventory and protection of cultural heritage of the past. In addition to the archaeological geographic information systems provide more detailed information about the history of the inhabiting peoples.

Creation of data banks and maps of the archaeological heritage allows to make a General historical picture of the study area and to identify the more important monuments which are subject to protection and restoration $[4,6]$. It is particularly important the creation of a GIS archaeological systems in the ancient and major historical centers in the Republic of Tatarstan.

\section{Tools and Methods of Research}

\section{Literature review}

A Significant contribution to the development of the national archaeological base of GIS was made by scientists from the Department of security excavations of the Institute of archaeology. G. E. Afanasyeva promoted introduction of new methods in under the management of D.S. Korobov the initiative group "Archaeological and geographical information systems" (AGIS) was created. Works of D. S. Korobov archeology. within the framework of the AGIS project, an Electronic journal was created, where AGIS is demonstrated immediately positively proved itself. Works, possibilities of application of GIStechnologies for solving problems: collection of information about cultural and historical monuments, its processing, cartographic visualization (including in the form of thematic maps), spatial modeling and cataloguing.

GIS technologies have become a tool for scientific historical analysis, with the help of GIS, developed specific methods for working with various historical data. Similar studies are conducted in the USA, England, Germany, Holland, Sweden. A number of universities offer special courses on the use of GIS technologies in historical research.

In Russia, developed interesting AI promising projects such as

AIS "Historian". A project of the Institute RAS (Saint Petersburg). "Development and creation of an archaeological information system for registration, accounting and analysis of archaeological monuments using digital maps and GIS.. AIS HISTORIAN gives the possibility of registering, recording and analysis of data stored in it to the archaeological sites at the present level. Special attention is paid to the development of the program interaction with geographic information systems for the subsequent spatial data analysis. This possibility allows you to operate with significant amounts of archaeological information using large-scale digital maps of the area due to the coordinate reference of each archaeological site.

The site GIS Spiritual and material culture of the peoples of Siberia, which contains information on the sacrificial covers, Mansi sanctuaries, attributes of the bear festival, bronze and silver Ob Ugrians. On the website Terminology GIS information center IA and Ethnography SB RAS. Per. With English. yaz. the most commonly used terms and abbreviations are given.

Website Geography Matters for Archaeological Research and Resource Management

GIS in archaeology contains reviews, publications, related resources, Discussion forum, software, on-line training.

The most important tool in archaeology is the use of electronic maps allows to make the analysis, areal and linear measurements, converting of data, and other operations on information processing [11-13].

As a source of information the following data were used:

- reports of explorations, excavations;

-archaeological map (6 volumes);

- historical maps;

- a set of monuments of the Republic of Tatarstan.

The collection of archaeological heritage in the Republic of Tatarstan contains the locations of archaeological monuments in the rayon, the plans of individual monuments and information about the monuments. Information about the monuments includes: 1) the Name and form; 2) the date and culture of the spindle; 3) nasal point and the river basin; 4) the text of the description of the monument; 5) references.

Historical paper archaeological maps, in contrast to the archaeological maps presented in 6 volumes, are more illustrative of the location of archaeological monuments on the territory of the Republic of Tatarstan and neighboring subjects.

Tools to research of archaeological monuments are: the routes of the intelligence services to verify information and accurately account area for archaeological research for their mapping and subsequent three-dimensional computer modeling of the identified structures tied to the natural landscape $[2,14]$. In work the following tools were used:

the global navigation satellite systems (GNSS) 
which allow to fix precisely on the modern land basis ancient anthropogenic and natural structures, new and already known archaeological objects; electronic tachometer. Routes for verification of the received data were passed.

The results of such a survey can highlight not only the contours of the settlement structures and the boundaries of the necropolis, the outlines of individual buildings, pits, graves, wells, excavations, traces of an ancient agricultural divisions, drainage and irrigation channels.

In laboratory conditions, these GNSS shooting are exported in a special program for information processing (ArcGIS, AutoCAD, IndorCAD, Maplnfo, Surfer, Credo, Pythagoras). Positioning of objects of archaeological heritage is carried out pointwise with use of the application of SAS
Planet by results of the verbal description.

The main advantages of using the total station in the survey of topographic plans of archaeological sites - is to increase the speed and accuracy of fixation with a significant reduction in time.

Methods of conducting surveys using satellite navigation equipment and using an electronic total station are the most accurate and significantly reduce the time for research, in contrast to outdated methods, but the cost of such work is very high.

For this search, you specify a location lying near the village. Using the description of the sources and the "line" tool and the "add new label" comes the application of the location of archaeological monument (Fig. 1).

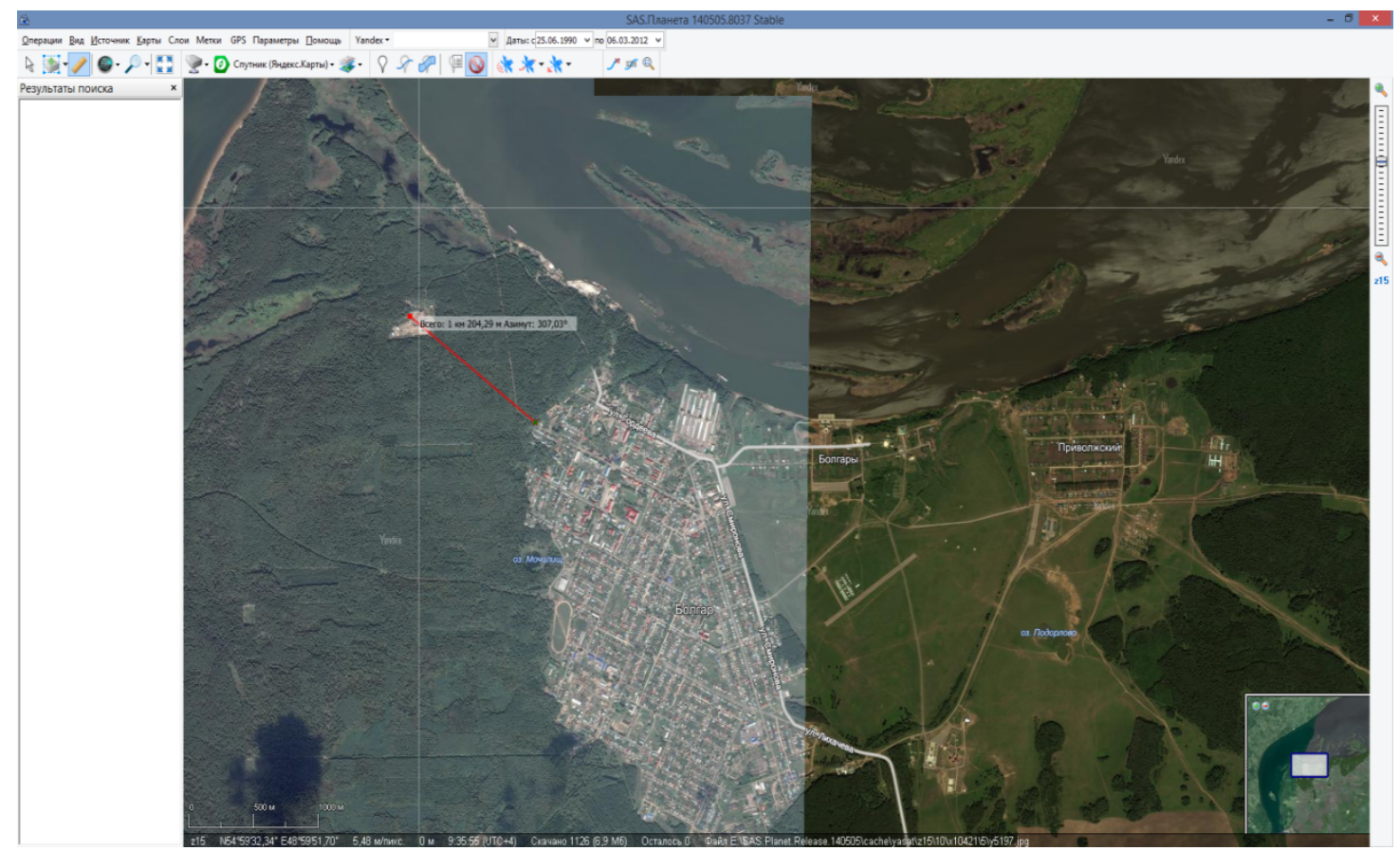

Figure 1. The application location of the monument using the program SAS. Planet

After applying all archaeological monuments vector layer with point data exported in the $\mathrm{kml}$ format, which is subsequently converted to the product family ArcMap geographic information system ArcGIS [4].

ArcMap represents geographic information as a set of layers and other map elements. A map typically has data frames that include map layers for a given extent, a scale bar, a North arrow, a title, explanatory text, a legend, and so on.

After projection and display of points of a monument fields with attributive information in the table of attributes on types of monuments of archeology for classifying and creation of legends, eras and cultural accessories of monuments are created.
For specification of location of an object and determination of coordinates of its borders GNSS the receiver is used. The tacheometer on archeological excavations is applied at breakdown of an excavation, fixing of finds and the opened objects (burials, ditches housing, economic holes. The file system of a tacheometer helps to create, keep and fill up files of different graphic fixings during excavation. By results of field works, with use of a satellite inventory, coordinates of rotary points of border of inspection transfer to a necessary frame means of ArcGIS. The obtained data use for preparation of the topographic map of borders of an object, with use by the accepted classification of legends(Fig. 2) 


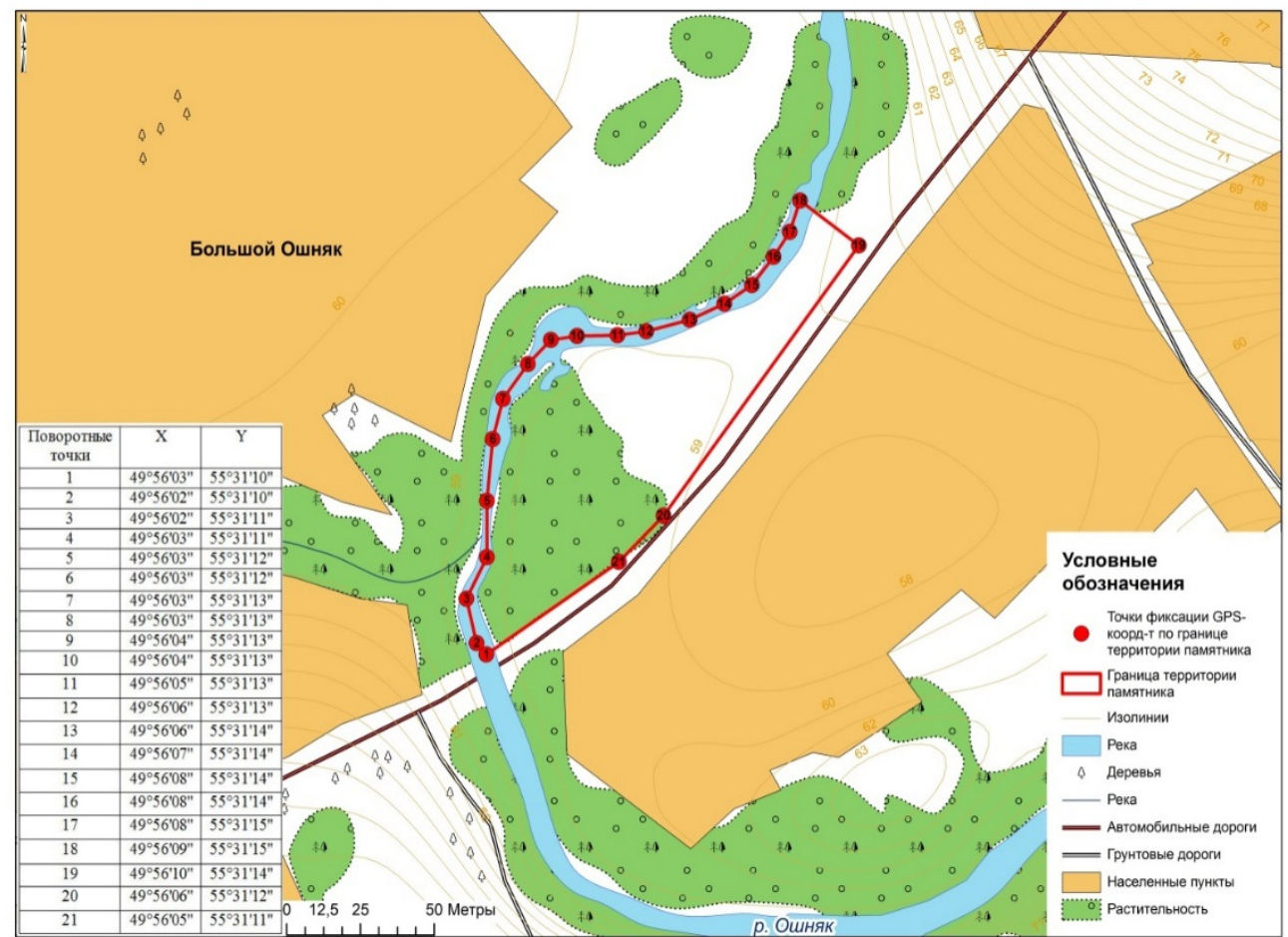

Figure 2. Topographical plan of borders of objects of archaeological heritage

Cartographic representation of objects of archaeological heritage of the Republic of Tatarstan is to prepare the topography of the various cartographic material, historical archaeological maps, literary (verbal) sources and survey data of the boundaries of the monument of archeology.

Various cartographic materials of different scales, as well as space and aerial photographs are used to clarify the location of the objects of the archaeological heritage of the Republic of Tatarstan when creating accurate maps of the archaeological heritage of the Republic of Tatarstan.

\section{Results and Discussions}

As a result of the performed works the GDB database on the ArcGis platform was created. This database of objects of archeology includes: name of an object of archaeological heritage; type of an object of archaeological heritage which includes the classification of monuments accepted in archeology (kurganny burial grounds, ground burial grounds, settlements, parking, dolmens etc); administrative accessory, the archeology monument address - the territorial subject of the Russian Federation, the administrative region / city, the settlement, a binding to the next settlement with the indication of distance in meters and an azimuth in degrees in text value, belonging to the river basin and landscape; geographical coordinates are given in a format of the coordinates recorded by means of GPS (degrees/minute/second or decimal shares of degree); data on a monument research (this information has help character as the reference to the source of information). Each type of an object of archaeological heritage is applied on the layer. A basis of the card is the topographic map of Tatarstan.

The base of geodata consists of all-geographical information and contains the following layers:

Administrative borders (ground); Airports (points); Bridges (points); horizontals (line); Lakes (ground); Power lines (line); Marks of heights (ground); Erosive processes (lines); Hydrography (ground, lines); Roads (line); Railroads (lines); Vegetation (ground, points); Settlements (ground, point).

Objects of archaeological heritage in the database are broken into groups: Borders of an object of archaeological (cultural) heritage (ground); Borders of an object of archaeological (cultural) heritage (point): Ancient settlement; Settlement; Parking; Burial ground; Cemetery; Gravestone; Barrow; Ggroups of barrows; Location; Stays. Thus, the structure of the database included not only space information but also text information and photodocumentation on archaeological objects. The received GIS great scientific value and also can find broad application as for bodies of protection of historical and cultural monuments, and administrative and economic organizations of territorial subjects of the Russian Federation.

By means of these data the card of Archaeological heritage of RT (Fig. 3) is constructed. 


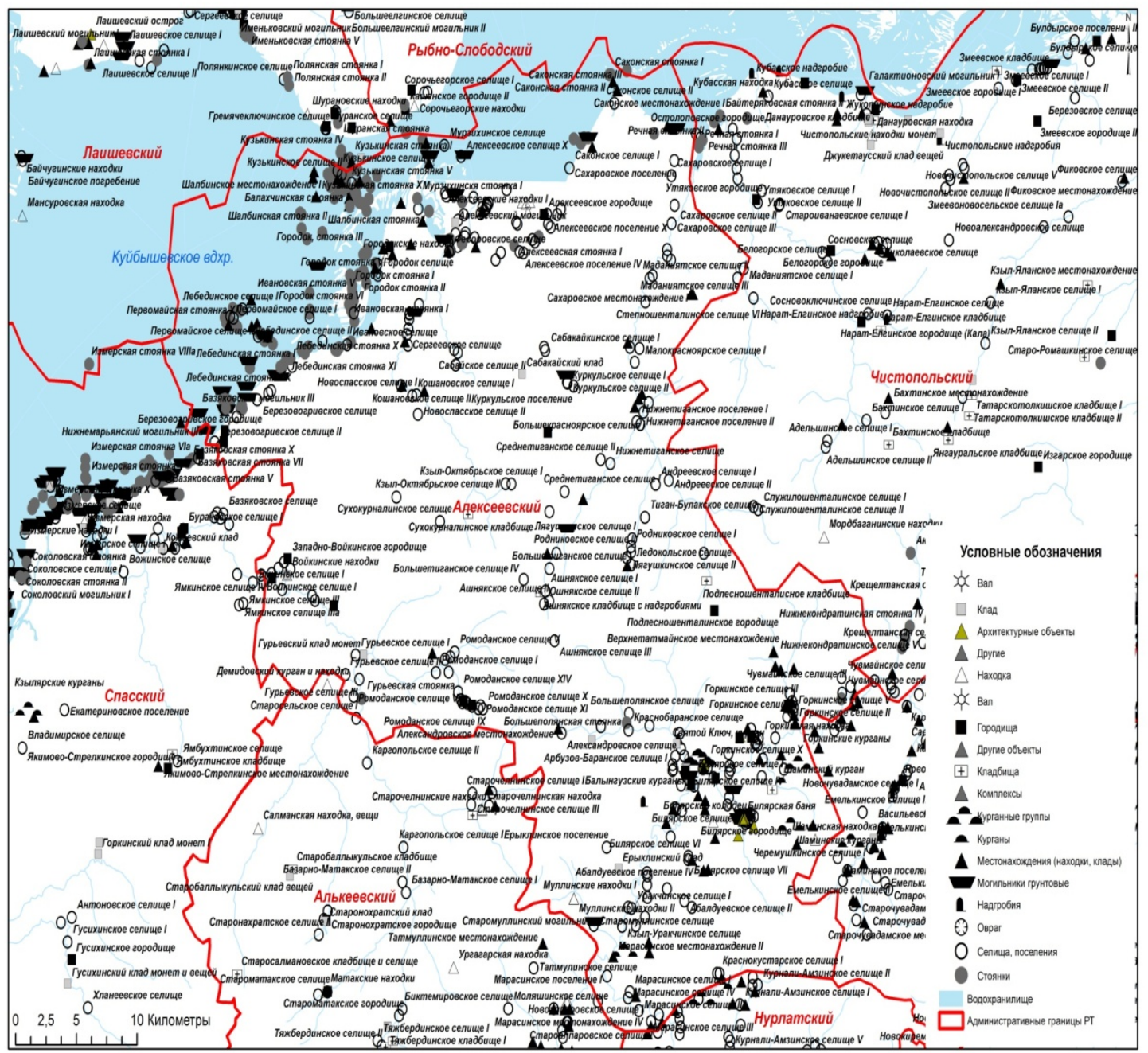

Figure.3. The map of Objects of archaeological heritage in the Republic of Tatarstan.

On the basis of the analysis of a spatial arrangement of data (measurement, different types of statistics, selection etc) maps of various thematic contents among which the maps of monuments representing in a quantitative sense various types of monuments of archeology of the administrative regions in the Republic of Tatarstan, the maps, a condition of objects on each area of the republic are received. Cards, an age of objects of archeology are received.

\section{Conclusion}

GIS of archaeological heritage in the Republic of Tatarstan allows for the collection, storing and linking data in digital form and to perform various tasks: research related to human exploration of the territory in the Republic for millennia; state management of the heritage: - state registered heritage properties - distribution, analysis and forecast of influence of factors of destruction (human and natural), - maintain the unified state register of objects of cultural heritage.

\section{Acknowledgments}

The work is performed according to the Russian Government Program of Competitive Growth of Kazan Federal University.

We would like to thank the staff of the Institute of archaeology. A. H. Khalikov of the Academy Sciences of the Republic Tatarstan for cooperation and providing materials for research, and also for the opportunity to perform this work at the Institute.

\section{References}

[1] Archaeological map of the Tatar ASSR. Western zakamje, ed. by P. N. Starostina. Part 1. - Kazan, 1986. - 112 p.

[2] Geoinformatics. kN. 1/Under.edited by Professor V. S. Tikunova. M.,2008. GL.1.

[3] Martynov, A. I., Sher, Y. A. Methods of archaeological research:' Proc. manual for University students. - M.: Higher. SHK., 1989. - 223 p. ISBN 5-06-000016-8

[4] Arch of archaeological monuments of the 
Republic of Tatarstan: 3T. / resp. ed. A. G. Sitdikov, F. sh. Khuzin - Kazan, 2007. Vol. 3. -528 p.

[5] Shakirov Z. G. Methods of fixation in archeology / Z. G. Shakirov. - Kazan: Kazan. UN-t, 2015. 114 p. [6] Afanas'ev, G.E. Aerospace analysis at the Middle Don region in Russia // Bournemouth University School of Conservation Sciences Research Report 6. Bournemouth and Moscow, 2000. P. 45-48.

[7] Belinskij, Andrey Multisystems approach used to prepare GIS Region" If International Conference on Remote Sensing Archaeology. Beijing, China, 2004. P. 305-306.

[8] Korobov D.S. IIntroduction to geoinformatics in archaeology: Manual. 2011.- Moscow: Moscow University Press, 224 pp.

[9] Krupochkin E.P.Methodological issues in the digital mapping of archaeological sites//

Archaeology, ethnology and Anthropology of Eurasia. 2009. T. 37. № 3. C. 95-102.

[10] Makarov N.A.; Zelentsova O.V., Korobov D.S., Chernikov A.P., Voroshilov A.N., 2015A. Geoinformatsionnaya sistema "Arkheologicheskie pamyatniki Rossii": metodicheskie podkhody $\mathrm{k}$ razrabotke i pervye rezul'taty napolneniya [GIS "Archaeological sites of Russia": Methodological approaches to the
development and first results of interpenetration]. KSIA [BCIA], 237, pp. 719.

[11] Martynov A.I., Sher Ya.A., 1989. Metody arkheologicheskogo issledovaniya [Methods of archaeological investigations]. Moscow: Vysshaya shkola. 223 p.

[12] Practical Applications of GIS for Archaeologists, 2000A. Predictive Modeling Toolkit // Konnie L. Wescott and R. Joe Brandon (eds). London: Taylor \& Francis,. $160 \mathrm{p}$.

[13] Srivastava, D. B. (2016).
ENERGY
SECURITY: ANOAY
TOMORROW. Humanities \& $\begin{array}{r}\text { Social } \\ \text { Sciences }\end{array}$ Reviews, 4(2),
h9-67.
https://doi.org/10.18510/hssr.2016.421

[14] Ingavale, D. (2013). An impact of advertisements on purchase decision of youth with reference to consumer goods. Advances in management, 3(1),18-22. 